\title{
KONTRIBUSI KELINCAHAN DAN KELENTUKAN DALAM OLAHRAGA SEPAK BOLA TERHADAP HASIL BELAJAR PENJASKES MURID KELAS I SDN 37 SUNGAI PENUH
}

\author{
Anggil Jufinda \\ STKIP Muhammadiyah Sungai Penuh \\ e-mail: anggiljufinda@gmail.com
}

\begin{abstract}
ABSTRAK
Merujuk kepada undang-undang no 3 tahun 2005 pasal 27 ayat 4 penelitian ini bertujuan untuk seberapa besar kontribusi kelincahan dan kelentukan terhadap hasil belajar penjaskes murid kelas 1 SDN 37 Sungai Penuh. Jenis penelitian adalah korelasional. Populasi dalam penelitian ini adalah seluruh murid SDN 37 Sungai Penuh sebanyak 149 orang, sedangkan teknik pengambilan sampel dilakukan dengan teknik purposive sampling dimana dalam penelitian ini adalah murid kelas 1 saja yaitu yang berjumlah 25 orang. Analisa data dilakukan dengan cara menggunakan korelasi product moment dan dilanjutkan uji kontribusi. Hasil penelitian menunjukkan bahwa ; tidak terdapat kontribusi antarakelincahan terhadap hasil belajar, diperoleh sumbangan 4\% dan hubungan $r_{\text {hit }} 0.20<r_{\text {tab }} 0.404$ (hubungannya lemah)/ tidak signifikan, terdapat kontribusi antarakelentukan terhadap hasil belajar murid SDN 37 Sungai Penuh diperoleh sumbangan $2.52 \%$ dan hubungan $r_{\text {hit }} 0.16<r_{\text {tab }} 0.404$ (hubungannya lemah)/ tidak signifikan, dan terdapat kontribusi antarakelincahan dengan kelentukan secara bersama-sama terhadap hasil belajar diperoleh sumbangan 34.81\%. Di sarankan kepada guru olahraga untuk memperhatikan faktor kelincahan dan kelentukan tersebut.
\end{abstract}

Kata Kunci : Kelincahan, Kelentukan, Hasil Belajar

Jurnal Edu Research

Indonesian Institute For Corporate Learning And Studies (IICLS) 


\section{PENDAHULUAN}

UU RI No. 3 pasal 27 ayat 4 (2005) menjelaskan; "Pembinaan dan pengembangan olahraga prestasi dilaksanakan dengan memberdayakan perkumpulan olahraga, menumbuhkembangkan sentral pembinaan olahraga yang bersifat nasional dan daerah, dan menyelenggarakan kompetisi secara berjenjang dan berkelanjutan". Sepakbola merupakan salah satu permainan yang paling banyak digemari banyak orang dan merupakan permainan yang sudah merakyat. Hal ini dapat dilihat bahwa di seluruh pelosok tanah air ada lapangan sepakbola dan banyak orang memainkannya, baik melalui klub-klub sepakbola maupun yang hanya sekedar hobi. Namun demikian perkembangan sepakbola Indonesia di lingkup Asia maupun Internasional belum seperti yang diharapkan.

Persepakbolaan di Indonesia saat ini sudah mengalami perbaikan walaupun masih tertinggal dengan negara Asia Tenggara lainnya seperti Thailand dan Vietnam. Hal yang menandai bangkitnya sepakbola di Indonesia yaitu adanya pembinaan atau pembibitan usia dini dimana pemain muda tersebut dilatih atau dibina dalam suatu kepelatihan seperti SSB (Sekolah Sepakbola).

Seorang pemain sepakbola untuk menjadi pemain yang handal harus memiliki kondisi fisik dan kualitas teknik dasar sepakbola yang baik. Muchtar(2012) menjelaskan "untuk dapat pandai bermain sepakbola, faktor fisik dan penguasaan keterampilan teknik dasar merupakan suatu keharusan. Agar fisik dan penguasaan keterampilan teknik dasar dikuasai perlu latihan yang sungguh-sungguh dan direncanakan dengan baik". Pendapat ini mengemukakan fisik dan teknik dasar merupakan beberapa faktor dalam penguasaan teknik dasar bermain sepakbola seorang pemain.

Salah satu indikator penilaian mata pelajaran penjaskes di sekolah adalah kemampuan bermain sepak bola. Hal ini dibenarkan oleh guru mata pelajaran penjaskes SDN 37 Sungai Penuh dalam wawancara yang dilakukan tanggal 3 Januari 2019, lemahnya penguasaan bola bagi murid-muridnya menyebabkan lemahnya perlawanan dalam pertandingan persahabatan di sekolah maupun di luar sekolah. Di samping itu gerakan murid terlihat kaku membuat sering terjadinya benturan dengan lawan yang menyebabkan cedera pada murid. Kemudian, seringkali mengalami kegagalan dan keterlambatan menyusun serangan terutama pada saat terjadinya serangan balik. Lemahnya kemampuan bermain sepak bola murid kelas 1 SDN 37 Sungai Penuh membuat indikator penilaian mata pelajaran penjaskes tidak terpenuhi, sehingga hasil belajar murid tersebut pun menjadi rendah.

Jurnal Edu Research Indonesian Institute For Corporate Learning And Studies (IICLS) 
Bertolak dari uraian di atas, maka tampaklah permasalahan yang akan diteliti, bahwa dalam permainan sepakbola diduga unsur kelincahan dan kelentukan untuk meningkatkan hasil belajar. Oleh sebab itu peneliti tertarik untuk membuktikan dengan penelitian secara ilmiah mengenai hubungan antara kelincahan dan kelentukan dalam bermain sepak bola terhadap hasil belajar murid SDN 37 Sungai Penuh.

\section{METODE PENELITIAN}

\section{A. Jenis Penelitian}

Jenis penelitian ini adalah penelitian kuantitatif dengan pendekatan uji korelasional, yang bertujuan untuk mengetahui dan menyelidiki sejauh mana hubungan atau peranan variabelvariabel predictor terhadap variabel yang diprediksi berdasarkan koefisien korelasi.Sesuai dengan pendapat Umar (2010) bahwa penelitian korelasional adalah suatu penelitian yang dirancang untuk menentukan tingkat hubungan variabel-variabel dalam suatu populasi yang bertujuan untuk mengetahui berapa besar kontribusi variabel bebas terhadap variabel terikat serta besarnya kaitan hubungan yang terjadi.Variabel bebas terdiri dari kelincahan dan kelentukan, sedangkan variabel yang diprediksi atau variabel terikat adalah hasil belajar murid kelas 1 SDN 37 Sungai Penuh.

\section{B. Tempat dan Waktu Penelitian.}

Penelitian ini dilaksanakan di lapangan binaan SDN 37 Sungai Penuh, sedangkan waktu pelaksanaan penelitian ini adalah pada bulan Januari 2019.

\section{Populasi dan Sampel \\ 1. Populasi}

Populasi adalah keseluruhan subjek penelitian (Arikunto, 2012). Pada penelitian ini yang dijadikan adalah murid SDN 37 Sungai Penuh

\section{Sampel}

Sampel adalah sebagian atau wakil populasi yang diteliti (Arikunto, 2012). Berpedoman kepada populasi penelitian dari ketiga kelompok umur yang terdapat di binaan Sepakbola Dusun Dalam, teknik yang digunakan adalah purposive sampling yaitu berdasarkan pertimbangan, maka yang memenuhi syarat untuk dijadikan sampel dalam penelitian adalah murid kelas 1 SDN 37 Sungai Penuh sebanyak 25 orang yang program latihannya telah mengacu kepada kebutuhan kondisi fisik sepakbola dan dapat melakukan pembelajaran dengan baik. Oleh sebab itu dalam

Jurnal Edu Research

Indonesian Institute For Corporate Learning And Studies (IICLS) 
penelitian ini dilakukan dengan menggunakan teknik purposive sampling yang merupakan pengambilan sampel bersyarat.

\section{Jenis dan Sumber Data \\ 1. Jenis Data}

Sesuai dengan tujuan yang hendak dicapai, maka jenis data dalam penelitian ini adalah data primer dan data sekunder.

a. Data primer

Data yang langsung diambil dari tes dan pengukuran terhadap atlet yang terpilih menjadi sampel, data tersebut meliputi :

1) Hasil Belajar

2) Kelincahan

3) Kelentukan

b. Data sekunder

Data yang diperoleh dari dokumen-dokumen yang diberikan oleh pelatih sepakbola yang bersangkutan seperti biodata murid dan lain-lain.

\section{Sumber Data}

Data yang diperoleh bersumber dari hasil tes kelincahan dan kelentukan serta hasil belajar bersumber dari pemain murid kelas 1 SDN 37 Sungai Penuh yang terpilih menjadi sampel.

\section{E. Teknik Pengumpulan Data}

Teknik pengumpulan data dalam penelitian ini adalah observasi ke lapangan, kemudian melakukan wawancara dengan guru mata pelajaran penjaskes dan melakukan tes pengukuran terhadap kelincahan, kelentukan dan hasil belajar murid kelas 1 SDN 37 Sungai Penuh.

\section{F. Instrumen Penelitian}

Instrumen yang digunakan dalam penelitian ini adalah :

1. Tes lari zig-zag (Nurhasan, 2014) digunakan dalam metode penelitian secara nasional.

2. Flexiometer (Morrow dalam Kementerian Negara Pemuda dan Olahraga Republik Indonesia, 2005).

3. Hasil belajar murid kelas 1 SDN 37 Sungai Penuh mencakup pree test dan post test

Jurnal Edu Research

Indonesian Institute For Corporate Learning And Studies (IICLS) 


\section{G. Teknik Analisa Data}

Sebelum dilakukan uji hipotesis dilakukan uji persyaratan analisis data dengan uji normalitas data (uji Lilliefors) pada signifikan 0,05. Kemudian setelah itu dikarenakan alat tes yang berbeda menyebabkan jumlah digit angka pada datapun berbeda sehingga haruslah dirubah kedalam bentuk T-Score dengan menggunakan formula T-Score dari Don R Sudjana(2012) yaitu dengan rumus sebagai berikut :

$$
T-\text { Score }=50 \pm 10\left(\frac{\mathrm{X}-\overline{\mathrm{X}}}{\mathrm{SD}}\right)
$$

Keterangan:

$$
\begin{aligned}
& \mathrm{X}=\text { Angka mentah } \\
& \bar{X}=\text { Angka rata-rata } \\
& \mathrm{Sd}=\text { Standar deviasi }
\end{aligned}
$$

Selanjutnya untuk memperoleh gambaran tentang karakteristik dari masing-masing variabel penelitian digunakan analisis statistik deskriptif dan distribusi frekuensi yang disajikan dalam bentuk tabel.

Berdasarkan pada hipotesis yang diajukan, analisis data yang dilakukan dapat dikemukakan sebagai berikut :

1. Hipotesis satu dan hipotesis dua diuji dengan menggunakan rumus korelasi product moment oleh Pearson dalam Sudjana(2012):

$$
r_{x y}=\frac{n \sum X Y-\left(\sum X\right)\left(\sum Y\right)}{\sqrt{\left\{n \sum X^{2}-\left(\sum X\right)^{2}\right)\left(n \sum Y^{2}-\left(\sum Y\right)^{2}\right.}}
$$

2. Hipotesis tiga diuji dengan menggunakan korelasi ganda menurut Sajoto(2010) menggunakan rumus sebagai berikut :

$$
R y \cdot X_{1} \cdot X_{2}=\sqrt{\frac{r^{2} 12+r^{2} 13-2 r_{12} r_{13} r_{23}}{1-r^{2} 23}}
$$

\section{Keterangan :}

Jurnal Edu Research 


$$
\begin{array}{ll}
\mathrm{R}_{123} & =\text { koefisien korelasi berganda } \\
\mathrm{r}_{\mathrm{xy}} & =\text { koefisien korelasi antara variabel } \mathrm{x} \text { dengan } \mathrm{y} \\
\sum \mathrm{X} & =\text { Jumlah data } \mathrm{x} \\
\sum \mathrm{Y} & =\text { Jumlah data } \mathrm{y} \\
\sum \mathrm{X}^{2} & =\text { Jumlah data kuadrat } \mathrm{x} \\
\sum \mathrm{Y}^{2} & =\text { Jumlah data kuadrat } \mathrm{y} \\
\mathrm{n} & =\text { Jumlah data (sampel) }
\end{array}
$$

\section{HASIL DAN PEMBAHASAN}

\section{A. Dekripsi Data}

Data dalam penelitian ini terdiri dari: kelincahan $\left(\mathrm{X}_{1}\right)$ dan kelentukan $\left(\mathrm{X}_{2}\right)$ sebagai variabel bebas dan hasil belajar (Y) sebagai variabel terikat. Selanjutnya akan diuraikan hasil penelitian yang mencakup: deskripsi data, uji persyaratan analisis hipotesis (uji normalitas) uji hipotesis dan pembahasan terhadap hasil penelitian.

\section{Kelincahan}

Dari hasil pengukuran kelincahan yang dilakukan terhadap 25 orang sampel murid kelas 1 SDN 37 Sungai Penuh kabupaten Kerinci, didapatkan skor tercepat 5.52 dan skor telambat 8.07 sedangkan range (jarak pengukuran) 50. Berdasarkan data kelompok tersebut rata-rata hitung (mean) 6.72 dan nilai tengah (median) 6.76, nilai sering muncul (mode) 6.66, simpangan baku (standar deviasi) 0.66 .

Selanjutnya distribusi kategori kelincahan murid kelas 1 SDN 37 Sungai Penuh dapat dilihat pada tabel 5 .

Tabel 5. Distribusi Frekuensi Kategori Kelincahan

\begin{tabular}{|c|c|c|c|}
\hline Skor & Kategori & Fa & fr \\
\hline $5.52-6.03$ & Baik Sekali & 3 & 12 \\
\hline $6.04-6.55$ & Baik & 8 & 32 \\
\hline $6.56-7.07$ & Sedang & 5 & 20 \\
\hline
\end{tabular}

Jurnal Edu Research

Indonesian Institute For Corporate Learning And Studies (IICLS) 


\begin{tabular}{|c|c|c|c|}
\hline $7.08-7.59$ & Kurang & 7 & 28 \\
\hline $7.60-8.11$ & Kurang Sekali & 2 & 8 \\
\hline & & 25 & 100 \\
\hline
\end{tabular}

Keterangan :

fa $\quad$ frekuensi absolut

fr $\quad$ : frekuensi relatif

Berdasarkan Tabel 2 di atas, dapat disimpulkan bahwa dari 25 orang atlet yang dijadikan sampel, yang memiliki kategori baik sekali adalah sebanyak 3 orang (12\%) dan kategori baik kelincahannya sebanyak 8 orang (32\%). Begitu juga dengan yang memiliki kategori sedang yaitu sebayak 5 orang $(20 \%)$ dan 7 orang $(28 \%)$ memiliki kategori kurang. Sedangkan untuk kategori kurang sekali yaitu 2 orang $(8 \%)$.

\section{Kelentukan}

Berdasarkan hasil tes kelentukan murid kelas 1 SDN 37 Sungai Penuh yang dilakukan terhadap 25 orang sampel, didapatkan skor tertinggi 23 dan skor terendah 9 sedangkan range (jarak pengukuran) 14. Berdasarkan data kelompok tersebut diperoleh nilai rata-rata hitung (mean) adalah 14.52, dan nilai tengah (median) 16. Sedangkan nilai sering muncul (mode) yaitu 14 dan simpangan baku (standar deviasi) sebesar 3.26.

Selanjutnya distribusi kategori kelentukan murid kelas 1 SDN 37 Sungai Penuhtersebut dapat dilihat pada tabel 6 .

Tabel 6. Distribusi Frekuensi Kategori Kelentukan

\begin{tabular}{|c|c|c|c|}
\hline Skor & Kategori & fa & fr \\
\hline $23-26$ & Baik Sekali & 1 & 4 \\
\hline $19-22$ & Baik & 1 & 4 \\
\hline $16-18$ & Sedang & 7 & 28 \\
\hline $12-15$ & Kurang & 11 & 44 \\
\hline $8-11$ & Kurang Sekali & 4 & 16 \\
\hline & & 25 & 100 \\
\hline
\end{tabular}

Jurnal Edu Research

Indonesian Institute For Corporate Learning And Studies (IICLS) 
Keterangan :

fa $\quad$ frekuensi absolut

fr : frekuensi relatif

Pada Tabel 3 di atas, dapat disimpulkan bahwa dari 25 orang sampel murid kelas 1 SDN 37 Sungai Penuhuntuk variabel kelentukan, yang memiliki kategori baik sekali adalah sebanyak 1 orang (4\%) dan untuk kategori baik 1 orang (4\%), dan 7 orang (28\%) memiliki kategori sedang. Sedangkan untuk kategori kurang yaitu sebanyak 11 orang (44\%) dan yang memiliki kategori kurang sekali sebanyak 4 orang $(16 \%)$.

\section{Hasil Belajar}

Dari hasil pree test dan post test yang dilakukan terhadap 25 orang sampel didapatkan skor nilai rata-rata murid kelas 1 SDN 37 Sungai Penuh 85, dengan capaian ketuntasan 85\%, artinya nilai tersebut telah memenuhi KKM yaitu 70.

\section{B. Uji Persyaratan Analisis}

Sebelum melakukan pengujian terhadap hipotesis yang diajukan dalam penelitian ini, maka terlebih dahulu di lakukan uji persayaratan analisis yang mencakup, Uji normalitas data sebagai berikut:

\section{Uji Normalitas Data}

Untuk mengetahui apakah data dari variabel yang diteliti berdistribusi normal atau tidak dapat digunakan uji Liliefors. Hasil uji Liliefors yang di observasi $\mathrm{L}_{\mathrm{o}}<\mathrm{L}_{\mathrm{t}}(\alpha=0.05)$, jika $\mathrm{L}_{\mathrm{o}}$ lebih kecil dari $\mathrm{L}_{\mathrm{t}}$ hal ini berarti kedua data variabel yang diteliti berdistribusi normal.

\section{Uji Independensi Antar Variabel Bebas}

Untuk mengetahui apakah ada kontaminasi antar variabel bebas dalam hubungannya dengan variabel terikat, maka pada analisis korelasi ganda sebaiknya dilakukan pengujian independensi antar variabel bebas. Hasil uji keberatian korelasi antara pasangan kelincahan $\left(\mathrm{X}_{1}\right)$ dengan kelentukan $\left(\mathrm{X}_{2}\right)$ diperoleh $\mathrm{t}_{\text {hitung }}=0.55<\mathrm{t}_{\text {tabel }} 2.02$ pada taraf signifikansi 0.05 , maka $\mathrm{H}_{\mathrm{a}}$ diterima dan $\mathrm{H}_{\mathrm{o}}$ ditolak.

Dengan demikian dapat disimpulkan bahwa tidak terdapat hubungan yang signifikan antara kelincahan $\left(\mathrm{X}_{1}\right)$ dengan kelentukan $\left(\mathrm{X}_{2}\right)$ murid kelas 1 SDN 37 Sungai Penuh. Dengan arti lain diartikan bahwa tidak terdapat kontaminasi hubungan antara variabel bebas dalam kaitannya dengan variabel terikat yaitu hasil belajar (Y).

Jurnal Edu Research

Indonesian Institute For Corporate Learning And Studies (IICLS) 


\section{Uji Hipotesis}

\section{Uji Hipotesis Kelincahan dengan Hasil Belajar}

Hipotesis pertama yang diajukan dalam penelitian ini adalah tidak terdapat kontribusi yang berarti (signifikan) antara kelincahan terhadap hasil belajar murid kelas 1 SDN 37 Sungai Penuh. Untuk menguji besarnya koefisien korelasi hipotesis tersebut dilakukan analisis korelasi product moment dan untuk menguji keberartian (signifikan) koefisien korelasi dilanjutkan dengan uji $\mathrm{t}$ korelasi. Hasil analisis korelasi antara kelincahan $\left(\mathrm{X}_{1}\right)$ dengan hasil belajar murid kelas 1 SDN 37 Sungai Penuh(Y) adalah $r=0.20$ artinya semakin baik kelincahan, maka semakin baik pula hasil belajar murid kelas 1 SDN 37 Sungai Penuh.

Selanjutnya untuk mengetahui berapa besar kontribusi variabel kelincahan $\left(\mathrm{X}_{1}\right)$ terhadap hasil belajar digunakan rumus determinan $r^{2} \times 100 \%$ atau $0.20^{2} \times 100 \%=4 \%$. Artinya kontribusi variabel kelincahan terhadap hasil belajar murid kelas 1 SDN 37 Sungai Penuhadalah sebesar 4\%, sedangkan sisanya disebabkan oleh variabel lain. Untuk menguji signifikan koefisien korelasi antara kelincahan terhadap hasil belajar dilakukan uji t. Hasil uji $t$ adalah $t_{\text {hitung }}$ $=0.98<\mathrm{t}_{\text {tabel }} 1.73 \alpha=0.05$. Dengan demikian dapat disimpulan bahwa hipotesis yang diajukan tidak terdapat hubungan yang berarti (signifikan) antara kelincahan terhadap hasil belajardan diterima kebenaran secara empiris.

\section{Uji Hipotesis Kelentukan dengan Hasil Belajar}

Hipotesis kedua yang diajukan dalam penelitian ini adalah tidak terdapat kontribusi yang berarti (signifikan) antara kelentukan terhadap hasil belajar diterima kebenaran secara empiris. Untuk menguji besarnya koefisien korelasi hipotesis ke dua tersebut dilakukan analisis korelasi product moment dan untuk menguji keberartian (signifikan) koefisien korelasi dilanjutkan dengan uji t korelasi. Hasil analisis korelasi antara kelentukan $\left(\mathrm{X}_{2}\right)$ dengan hasil belajar(Y) adalah $\mathrm{r}_{\text {hit }} 0.16<\mathrm{r}_{\text {tab }} 0.404$ artinya semakin baik kelentukan, maka tidak terbukti semakin baik pula hasil belajar pada murid kelas 1 SDN 37 Sungai Penuh.

Untuk mengetahui berapa besar kontribusi variabel kelentukan terhadap hasil belajar digunakan rumus determinan $\mathrm{r}^{2} \times 100 \%$ atau $0.16^{2} \times 100 \%=2.56 \%$. Artinya walaupun hubungannya tidak signifikan tetapi kelentukan tetap bekontribusi terhadap hasil belajar tersebut yang persentasenya kecil yaitu $2.56 \%$ sedangkan sisanya disebabkan oleh variabel lain. Untuk menguji signifikan koefisien korelasi antara kelentukan terhadap hasil belajarmurid kelas 1 SDN 37 Sungai Penuh dilakukan uji t. Hasil uji $\mathrm{t}$ adalah $\mathrm{t}_{\text {hitung }}=0.97<\mathrm{t}_{\text {tabel }} 1.73 \alpha=0.05$. Dengan demikian dapat disimpulkan bahwa hipotesis yang diajukan tidak terdapat hubungan yang berarti (signifikan) antara kelentukan terhadap hasil belajardan diterima kebenaran secara empiris.

\section{Pengujian Hipotesis Kelincahan dan Kelentukan dengan Hasil Belajar}

Hipotesis ketiga yang diajukan dan dirumuskan bahwa tidak terdapat kontribusi yang berarti (signifikan) antara kelincahan $\left(\mathrm{X}_{1}\right)$ dan kelentukan $\left(\mathrm{X}_{2}\right)$ secara bersama-sama terhadap hasil belajar murid kelas 1 SDN 37 Sungai Penuh. Pengujian hipotesis ke tiga ini dilakukan

Jurnal Edu Research

Indonesian Institute For Corporate Learning And Studies (IICLS) 
menggunakan korelasi ganda. Berdasarkan hasil perhitungan uji signifikansi korelasi ganda diperoleh $\mathrm{F}_{\text {hitung }}=16.04>\mathrm{F}_{\text {tabel }}$ 3.47, maka $\mathrm{H}_{\mathrm{o}}$ ditolak dan $\mathrm{H}_{\mathrm{a}}$ diterima. Artinya terdapat kontribusi yang berarti antara $\mathrm{X}_{1}$ dan $\mathrm{X}_{2}$ secara bersama-sama dengan $\mathrm{Y}$.

Selanjutnya berdasarkan kekuatan hubungan yang diperoleh dari korelasi ganda (Ry.12) diperoleh sebesar 0.59 dan koefisien determinasi 0.34816 dapat dilihat kontribusi antara kelincahan dan kelentukan terhadap hasil belajardengan rumus $0.59^{2} \times 100 \%=34.81 \%$. Dengan arti kata kontribusi kelincahan dan kelentukan secara bersama-sama terhadap hasil belajaradalah sebesar $34.81 \%$.

Berdasarkan hipotesis di atas, maka dapat disimpulkan bahwa kelincahan dan kelentukan secara bersama-sama mempunyai kontribusi atau sumbangan yang signifikan terhadap hasil belajar murid kelas 1 SDN 37 Sungai Penuh.

\section{Pembahasan}

Temuan pertama, tidak terdapat kontribusi yang berarti (signifikan) antara kelincahan dengan hasil belajar diterima kebenaran secara empiris. Hal ini menunjukkan bahwa salah satu variabel yang dapat mempengaruhinya. Berpedoman pada pendapat yang telah dikemukakan di atas dapat diambil kesimpulan bahwa kelincahan dibutuhkan dalam semua cabang olahraga. Kelincahan memegang peran yang sangat penting. Olahraga permainan sepakbola yang sangat membutuhkan kelincahan, terutama sekali dalam melakukan pertahanan seperti melakukan variasi serangan kegawang.

Temuan kedua, tidak terdapat kontribusi yang berarti (signifikan) antara kelentukan dengan hasil belajar diterima kebenaran secara empiris. Kemampuan kelentukan yang tinggi perlu diusahakan dengan memberikan latihan yang dapat meningkatkan kelentukan terbagi menjadi 2 (dua) yaitu: latihan kelentukan secara dinamis dan latihan kelentukan secara statis (yang berupa latihan peregangan). Latihan peregangan yang berfungsi untuk meningkatkan kelentukan tubuh adalah peregangan persendian leher, bahu, togok, pinggang dan tungkai.

Temuan ketiga, tidak terdapat kontribusi yang berarti (signifikan) antara variabel kelincahan $\left(\mathrm{X}_{1}\right)$ dan kelentukan $\left(\mathrm{X}_{2}\right)$ secara bersama-sama terhadap hasil belajarmurid kelas 1 SDN 37 Sungai Penuh. Berdasarkan hasil perhitungan uji signifikansi korelasi ganda diperoleh $\mathrm{F}_{\text {hitung }}=12.3>\mathrm{F}_{\text {tabel }} 3.47$, maka $\mathrm{H}_{\mathrm{a}}$ ditolak dan $\mathrm{H}_{\mathrm{o}}$ diterima. Artinya tidak terdapat hubungan yang berati antara kelincahan $\left(\mathrm{X}_{1}\right)$ dankelentukan $\left(\mathrm{X}_{2}\right)$ secara bersama-sama terhadap hasil belajar murid kelas 1 SDN 37 Sungai Penuh (Y).

Selanjutnya berdasarkan kekuatan hubungan yang diperoleh dari korelasi ganda (Ry. $\left.{ }_{12}\right)$ diperoleh sebesar 0.56 dan koefisien determinasi 0.3481 dapat dilihat hubungan kelincahan dan kelentukan terhadap hasil belajar dengan rumus $r^{2} \times 100 \%=0.56^{2} \times 100 \%=34.81 \%$. Dengan arti

Jurnal Edu Research

Indonesian Institute For Corporate Learning And Studies (IICLS) 
kata hubungan kelincahan dan kelentukan terhadap hasil belajar memberikan hubungan sebesar $34.81 \%$ terhadap hasil belajarmurid kelas 1 SDN 37 Sungai Penuh.

Selanjutnya adalah variabel kelentukan ini sudah termasuk juga di dalam unsur variabel kelincahan, secara sendiri variabel kelentukan berhubungan lemah dengan hasil belajar, tetapi secara bersama-sama kelentukan dan variabel kondisi fisik lain berhubungan dengan hasil belajar sepak bola. Sesuai menurut Harsono (2001) "tanpa kelentukan, orang tidak akan bergerak lincah dan kelincahan bukan hanya menuntut kecepatan, akan tetapi juga kelentukan yang baik dari sendi-sendi anggota tubuhnya".

\section{KESIMPULAN}

Berdasarkan hasil penelitian maka dapat ditarik kesimpulan sebagai berikut:

1. Tidak terdapat kontribusi yang berarti (signifikan) kelincahan terhadap hasil belajar murid kelas 1 SDN 37 Sungai Penuh dan diperoleh sumbangan sebesar 4\% dan hubungan $r_{\text {hit }} 0.20<$ $\mathrm{r}_{\text {tab }} 0.404$ (hubungannya lemah).

2. Tidak terdapat kontribusi yang berarti (signifikan) antara kelentukan terhadap hasil belajar murid kelas 1 SDN 37 Sungai Penuh dan diperoleh tingkat capaian sebesar $2.56 \%$ dan hubungan $\mathrm{r}_{\text {hit }} 0.16<\mathrm{r}_{\text {tab }} 0.404$ (hubungannya lemah).

3. Tidak terdapat kontribusi yang berarti (signifikan) antara kelincahan dan kelentukan secara bersama-sama terhadap hasil belajar murid kelas 1 SDN 37 Sungai Penuh dan diperoleh sumbangan sebesar $34.81 \%$ dan sedangkan sisanya dipengaruhi oleh variabel lain dan diterima kebenaran secara empiris.

\section{UCAPAN TERIMAKASIH}

Terimakasih kepada kepala SDN 37 Kota Sungai Penuh dan seluruh majelis guru yang telah memberikan motivasi sehingga penelitian ini terlaksana dengan baik.

\section{DAFTAR PUSTAKA}

Arikunto, Suharsimi. 2012. Prosedur Penelitian. Jakarta : Rineka Cipta

Kementerian Negara Pemuda dan Olahraga RI. 2005. Sistem Keolahragaan Nasional. Jakarta : Presiden RI

Muchtar, Remmy. 2012. Olahraga Pilihan Sepak Bola. Depdikbud. Proyek Pembinaan Tenaga Kependidikan

Nurhasan. 2014. Tes dan Pengukuran Pendidikan Olahraga. Bandung: FPOK IKIP Padang PSSI. 2008. Law Of The Game. Jakarta: FIFA

Jurnal Edu Research

Indonesian Institute For Corporate Learning And Studies (IICLS) 
Volume 1, Nomor 1, Desember 2019

Sudjana. 2012. Metode Statistik(Edisi IV). Bandung : Tarsito Sajoto. M. 2010. Pembinaan Kondisi Fisik dalam Olahraga, Semarang: Depdikbud Umar, Husen. 2010. Metode Penelitian untuk Skripsi dan Tesis Bisnis. Jakarta: Raja Grafindo Persada

Jurnal Edu Research

Indonesian Institute For Corporate Learning And Studies (IICLS) 